International Journal of Business and Management Review

Vol.8, No.3, pp.14-33, May 2020

Published by ECRTD-UK

Print ISSN: 2052-6393(Print), Online ISSN: 2052-6407(Online)

\title{
TOWARDS IMPROVING THE EFFECTIVENESS OF THE PUBLIC PROCUREMENT RULES OF BANGLADESH: LESSONS FROM THE UNITED NATIONS PROCUREMENT MANUAL
}

\author{
Mohammed Salah Uddin \\ Deputy Director (Senior Assistant Secretary) \\ Central Procurement Technical Unit (CPTU) \\ Implementation Monitoring and Evaluation Division (IMED), Ministry of Planning \\ Dhaka, Bangladesh \\ Md. Aknur Rahman \\ Deputy Director (Deputy Secretary), Central Procurement Technical Unit (CPTU) \\ Implementation Monitoring and Evaluation Division (IMED), Ministry of Planning \\ Dhaka, Bangladesh
}

\begin{abstract}
Every year Bangladesh has to incur about 14 billion USD through Annual Development Program (ADP) for the procurement of goods, works and services in the public sector. Bangladesh has her home grown laws and regulations to ensure transparency, accountability, fairness, open competition to ensure value for money in the public spending. To this end, Bangladesh is constantly adapting international standard practices. United Nations (UN) has a unique procurement manual through which it procures all the goods, works and services. The standards followed by the UN can be compared with those of the Public Procurement Rules (PPR) of Bangladesh and lessons can be incorporated in Bangladesh to streamline the public procurement.
\end{abstract}

KEYWORDS: procurement, goods, works, services, ethics, committees, evaluation criteria

\section{INTRODUCTION}

Bangladesh (BD) is a low middle income country having a robust annual GDP (Gross Domestic Product) growth rate of around 7.5\%. It is very imperative to maintain this growth rate and to this end, effective and efficient use of limited resources is of paramount importance. About US\$ 14 billion has been invested through Annual Development Program (ADP) in Bangladesh and 65\% to $75 \%$ of that ADP is invested for public procurement. This huge investment in the public procurement demands the streamlining of the Public procurement act, rules and related issues for ensuring better value for money. Public Procurement of Bangladesh is carried out in accordance with the Public Procurement Act (PPA), 2006 and Public Procurement Rules (PPR), 2008. To 
International Journal of Business and Management Review

Vol.8, No.3, pp.14-33, May 2020 Published by ECRTD-UK

Print ISSN: 2052-6393(Print), Online ISSN: 2052-6407(Online)

carry out the purpose of these act and rules, Central Procuring Technical Unit (CPTU) was established under Implementation, Monitoring and Evaluation Division (IMED) of the Ministry of Planning. As per the act and rules CPTU has the power to monitor compliance, to propose any amendment of act, rules and other tender documents. It also has the authority to issue guidance and instruction relating to the implementation of the act and rules and to prepare Standard Tender/Proposal Documents (STD/SPD) for the procurement of goods, works and services. Every Procurement entity use these standardized documents for public procurement. These documents are formulated based on the PPA-2206 \& PPR-2008. The United Nations (UN) being one of the largest organizations in the world employ huge number of consultants every year. The UN follows its own procurement guidelines issued by the Department of Management, Office of the Central Support Services at Procurement Division in UN Headquarters at New York. UN procurement guidelines incorporates the pros and cons of selecting of consultants and acquiring goods and works. This paper investigate the gaps in the standard procurement practices in PPR of Bangladesh which will go a long way to make some policy change in the existing procurement instruments in Bangladesh and thus contribute towards ensuring the value for money in the public sector.

\section{Research Objective}

The prime objective of this study is to make a critical review of the existing procurement rules of Bangladesh with a view to improving its effectiveness by eliciting lessons from the relevant UN instruments (notably UN Procurement Manual).

\section{Specific objectives}

The specific objectives of the study are as follows:

i. To provide an overview of the existing status and history of public procurement regulations in $\mathrm{BD}$.

ii. To critically examine the strengths and weaknesses of the PPR-2008 as the key procurement regulation.

iii. To review the provision of the UN Procurement Manual as the major procurement instrument for UN in order to identify relevant lessons and clues on improvement for Bangladesh.

\section{Research Questions}

i. What is the current status of the Public Procurement Regulations of Bangladesh? 
ii. What are the strengths and weaknesses PPR-2008 of Bangladesh as a key public procurement document?

iii. What are the relevant lessons from the UN Procurement Manual that can be drawn for improving the effectiveness of the Public Procurement regime in Bangladesh?

Scope and limitation of the study Before 2003, there was no specific act to regulate Public Procurement of Bangladesh. In 2003, government of Bangladesh has promulgated an instrument titled "Public procurement Regulation-2003". In 2006, "Public procurement Regulation-2003" had been repealed and a new act titled "Public procurement Act-2006" was enacted. Subsequently, to implement the Public Procurement act, the government of Bangladesh enacted "Public Procurement Rules-2008". Therefore, PPA-2006 and PPR-2008 are the main instruments for Pubic Procurement in Bangladesh. As PPR-2008 is more elaborated and inclusive, for the sake of this study, PPR-2008 is taken in to consideration. This study will be confined to the latest amended PPR-2008. On the other hand, the UN as a leading international procuring entity, uses UN Procurement Manual as the major procurement instrument for UN. This instrument is updated based on the actual needs. For this study, version 7 which is published on $1^{\text {st }}$ July 2013 is taken in to cognizance.

\section{METHODOLOGY}

This study employs the following tools and techniques:

Review of secondary literature While preparing this paper, various sources of secondary literatures such as published journals, articles, research papers, working papers have been used. The predominant sources are Journal of Transport and Supply Chain Management, (Vol. 6 Issue: 1), Journal of Public Procurement, (Vol. 7 Issue: 1, pp.3-33), A United Nations Sustainable Development Journal, The European Journal of Social Science Research, (Development-based public procurement policies: a selective survey of literature, cross-country policy experience and the Turkish experience, Innovation).

Official document review For conducting the study, different office orders, circulars, explanation and clarifications issued by the CPTU, resolutions of the meeting held at CPTU with the key public stakeholders including contractors, and consultants are explored. Moreover, the related file, letters, complaints in the review panel, basis of decision are also consulted and taken care of. These documents are not available in the public domain.

Personal observation Since the author of this study has been posted at the Central procurement technical Unit (CPTU) which is the nodal agency and main regulatory body for public procurement, he had the opportunity to oversee how the current public procurement regime works in Bangladesh, what are the reaction of the main stakeholders about the main public procurement instrument, what are the strengths and weaknesses of these public procurement instruments. Being 
an official of CPTU, the author has his own practical experience, insight and observation which shaped the findings of the study.

Rationale of the Study In the recent years, public expenditure of Bangladesh has been tremendously increased and the country has been experiencing a robust economic growth. It is estimated that about $80 \%$ of the total annual ADP has been utilized for procurement purpose. In order ensure value for money, the government has taken initiative to mainstream the procurement activities of the government agencies. To this end, a nodal body, titiled "Central procurement Technical Unit (CPTU)" under the guidance and supervision of IMED of the Ministry of Planning has established. CPTU has been the given the mandate to implement rules, preparing tender documents, giving opinion regarding the applicability of the procurement rules. So far, CPTU has prepared 37 documents for the procurement of goods, works and related services. Documents related to intellectual and professional services are denoted as 'PS'- that is procurement of services. In the procurement of services, the procuring entities are supposed to follow the required proposal document. In another side of the spectrum, UN has also devised various tender documents through which it procures. UN tender/ proposal document incorporates some unique features and characteristics, which are different those that of Bangladesh. Therefore, in order to find out the gaps, areas of differences, uniqueness, in between them, this current study is undertaken. This will help identifying the major differences, strengths, weakness, the areas of improvement in between the provisions of UN procurement Manual and those published by the CPTU.

A Review of the Key Lliterature While reviewing the contemporary literature regarding the public procurement management it is found that there were some fundamental concepts and terminologies in the area of public procurement. For example, procurement are sub-divided in to three major headings, like, procurement of goods, works and intellectual and professional services. Under public procurement system in Bangladesh, a tender or proposal is approved by the approving authority which is defined as the authority, which in accordance with the Delegation of Financial Powers, approves the award of contract. The procuring entity is the entity having administrative and financial powers to undertake the procurement. Head of the Procuring Entity (HOPE) means the Secretary of a Ministry or a Division, the Head of a Government Department, or Directorate, or the Chief Executive, Divisional Commissioner, Deputy Commissioner, District Judge, or by whatever designation called, of a local Government agency, an autonomous or semiautonomous body or a corporation or a corporate body established under the Companies Act. There are some empirical studies on the value creation through public procurement for developed, least developed countries and developing countries. As part of the public financial management tool, a smart and efficient public procurement system helps in reducing waste and curbing corruption (Jones 2007). A well-functioning public procurement system directs the public expenditure management in a disciplined way and it helps taking budgetary decision and identifying of the best 
International Journal of Business and Management Review

Vol.8, No.3, pp.14-33, May 2020

Published by ECRTD-UK

Print ISSN: 2052-6393(Print), Online ISSN: 2052-6407(Online)

economically feasible investment opportunity for the government (McCrudden 2004). However, another study (World Bank, 2017) revealed that there are many countries whose public procurement system is limited by the several negative factors and the need for streamlining the public procurement system is getting more attention. The study on the experience of South Africa reveals that insufficient procurement skills, rampant corruption, and lack of accountability are predominant in that country (Ambe \& Badenhorst-Weiss, 2012). There are several other studies which shows that developing countries lack in transparent and efficient public procurement system. In the context of public procurement literature, public procurement system can be seen as the link between the requirements of the public- the state as a whole and the private sector service provider. Sometimes, public procurement is regarded as the oxygen of development. These theories and empirical results shows the importance of an efficient public procurement system. However, no study is found in Bangladesh to improve the effectiveness of introduction of PPR in compared to the lessons learned from the relevant UN procurement instrument. This paper tries to fill this gap.

\section{An Overview of PPR of Bangladesh}

History and background Bangladesh had been carrying the legacy of the then British rules regarding the public procurement of Bangladesh. General Financial Rules (GFR) were the instruments based on which public expenditure is controlled and regulated. After the birth of Bangladesh in 1971, ministry of finance is given the mandate to issue necessary circulars to maintain financial disciple as far as public procurement is concerned. Government of the people's republic of Bangladesh in its gazette notification on the $24^{\text {th }}$ January 2008 enacted the public procurement rules in exercise the powers conferred under section 70 of the PPA 2006(Act 24 of 2006). The latest amendment has been published the gazette on $24^{\text {th }}$ November 2016 . PPR consists of 130 rules, nine chapters, and fourteen schedules.

\section{Chapter wise Main Provisions of PPR}

Chapter one PPR- 2008 shall apply to the procurement of goods are related services, works and physical services, and intellectual and professional services using public funds, fund of any government or semi-government, or any statutory body established by the law, or any loan, grant or credit given to any organization through government (unless and otherwise specified in the agreement).

Chapter two This chapter comprises the provisions related to preparation of tender/proposal and formations of different committees. There are four types of committee in the PPR-2008, namely, (Tender Opening Committee) TOC or Proposal Opening Committee (POC), Tender Evaluation Committee (TEC) or Proposal Evaluation Committee (PEC), Technical Sub- committee, and 
International Journal of Business and Management Review

Vol.8, No.3, pp.14-33, May 2020

Published by ECRTD-UK

Print ISSN: 2052-6393(Print), Online ISSN: 2052-6407(Online)

Official Cost Estimate Committee. TOC or POC is consists of three member, one of whom shall be chairperson. TEC or PEC shall comprise minimum five or seven members out of whom two member will be from the other externa organization. For any evaluation report to be valid, signature of two external members is mandatory.

Chapter three This chapter gives the indication of the major principles of public procurement. It is divided in to two parts, namely, general guidelines, and tender validities and security deposits which ranges from rule number 13 to rule number 60 . For undertaking any public procurement, it is to be included in the procurement plan. This procurement plan can be updated quarterly basis. In general, a tender or proposal shall remain for the period ranging from 60 to 120 dys.

Chapter Four This chapter incorporates the methods of procurement (National and International) related to goods and works and ranges from rule number 61 to rule number 89. As per PPR-2008, OTM is recognized as the preferred method for the procurement of goods and works. There are seven other methods which can be used with the approval of the HOPE if the prevailing circumstances allow.

Chapter five This chapter takes in to cognizance of the processing of procurement which ranges from rule 90 to 102. The spirit of PPR-2009 is to ensure free and open competition. To this intent, it is expected to advertise the tender or Expression of Interest, very widely, if applicable, internationally. All the tenders or proposals received duly are opened by the TOC or POC as per the provision of rule 97. Then those tenders or proposals are sent to TEC or PEC, formed under rule 8 to rule 12 for evaluation. The evaluation committee evaluate the tenders or proposals based on the pre-disclosed objective criteria. Generally, no lottery is allowed in case of procurement of goods or work except Limited Tendering Method (LTM). Therefore, negotiation is allowed only for Direct Procurement Method (DPM), and for the procurement of professional and intellectual services.

Chapter six This chapter includes the provisions relating to procurement of professional and intellectual services which also ranges from rule 103 to rule 126. Rule 103 to Rule 112 speaks about the methods and procedures. As per PPR-2008, there eight specific methods for the procurement of intellectual and professional service. In that case, either time based or lump-sum contract is followed. Among the existing eight methods, there are only two preferred methods, namely, Quality and Cost Based Selection (QCBS) and Fixed Budget Selection (FBS).

Chapter seven This chapter deals with only one rule, i.e. rule 127 which describes the provisions regarding the professional misconduct. 
International Journal of Business and Management Review

Vol.8, No.3, pp.14-33, May 2020

Published by ECRTD-UK

Print ISSN: 2052-6393(Print), Online ISSN: 2052-6407(Online)

Chapter eight This chapter (rule 128) empower the government to implement Electronic Government Procurement in Bangladesh.

Chapter nine: This is a miscellaneous chapter incorporates the special contracts and the rules and responsibilities of the government in the field of public procurement.

\section{A Critique of PPR (Strengths and Weaknesses)}

The strengths of the existing public procurement regulation are outlined below:

Formation of different committees The existing public procurement regulations includes different types of committee for different purposes, for example, TEC/ PEC for evaluation, Technical subcommittee for evaluation, TOC/ POC for opening of tenders or proposals, Committee for preparation of Official Cost Estimate, Acceptance Committee, Committee for Enlistment. Terms and references of these committees are independent of each other. They ensure the accountability, transparency and neutrality in the processing of the tenders and proposals. For example, rule 8(12) states that each member of the TEC/POC has to sign individually and collectively a letter of impartiality during conducting evaluation of tender or proposal.

Safeguard against corruption The PPR of Bangladesh has a very strong stance against professional misconduct. The PPA-2006, PPR-2008 and the STD.s and SPDs ensure that the procuring entities and other persons who are related to the procuring process must abide by the provision of the act (Section 64 of PPA) and the codes of practice mentioned in the second schedule of PPR-2008. The PPR-2008 states that any tenderer or consultant having the engagement towards corrupt, fraudulent, collusive and coercive practices may be debarred or excluded from further participation in the public procurement, and if any person/staff/member/ of the procuring entity is engaged in corrupt, fraudulent, collusive and coercive practices, he/she shall be punished under the "Discipline and Appeal Rules-1985" or under " Anti-Corruption Commission Act-2004", or under " The Prevention of Corruption Act-1947". These above issues give the signal of good governance in the implementation of the existing public procurement regulations of Bangladesh.

Non-discriminatory The PPR of Bangladesh is non-discriminatory. The main objective of the PPR is to ensure free and fair competition in the field of public procurement for ensuring better value for money. Rule 47 of the PPR-2008 states that as for general rule, no discrimination is allowed until and unless it is prohibited by the government. At the same time, rule 95(5) if anyone is interested to buy tender document in the payment of required price, then the procuring entity, in no way, restrain him/ her from buying that tender document. This non-discriminatory nature of the PPR is a very positive aspect which encourages the open and equal participation of all the tenderer. 
International Journal of Business and Management Review

Vol.8, No.3, pp.14-33, May 2020

Published by ECRTD-UK

Print ISSN: 2052-6393(Print), Online ISSN: 2052-6407(Online)

Provision of digitization Section 65 of the PPA-2006 states that the government may implement Electronic Government Procurement (E-GP) system in the public procurement process. In order to implement this, rule 128 of the PPR-2008 also echo the same thing. As part of the initiative of the digital Bangladesh, Bangladesh had been experiencing a tremendous improvement in the area of E-GP. This digitized system has brought about a revolutionary change in the public procurement in Bangladesh. Due to this on-line tendering system, lead time for tender processing has decreased, reliability and accountability has been increased.

Moreover, the PPR of Bangladesh has some downside aspects which are mentioned below:

Absence of the issues of Total Cost of Ownership (TOC) The present PPR of Bangladesh does not count the issues related to the Whole Life Costing (WLC), TCO, and Life Cycle Costing (LCC) which are very important in determining the actual cost of the product or service. Under the current provisions, there is no scope to consider the scrape value or salvage value of the asset that may accrue at the end of the expected life of the asset. Therefore, the contract price that is derived with this process may reflect the best value for money.

Performance evaluation of the vendors Under the provisions of the PPR, there are no room for the determining the rating of the vendor's performance. What is done is that, under limited tendering method, a list of enlisted tenderers/ vendors are maintained with the PEs. This list is updated and renewed, but no rating is applied which can be used for further procurement.

Limiting the scope of specification The wider spectrum of specification as mentioned in the rule 29 (PPR-2008) is not considered in the current PPR of Bangladesh. Specification is viewed on the view point of conformance and performance only. There are other facets of specification such as specification by sample, specification by grades, specification by standards or specification by the chemical properties are ignored. As specification is the heart of the contract, if these categories of specification are incorporated in to the PPR, it could be more representative.

\section{A Review of the UN procurement Manual}

History and background Procurement functions of the United Nations are guided by the Financial Regulations and Rules which, for the first time, promulgated by the office of the Secretary General of the UN in 2003. Since then, the UN updated its procurement guidelines on interval basis. Latest version (Version 7) UN Procurement Manual has been published on $1^{\text {st }}$ July, 2013 by the Department of Management, Office of Central Support Services, procurement Division on, United Nations. 
Vol.8, No.3, pp.14-33, May 2020 Published by ECRTD-UK

Print ISSN: 2052-6393(Print), Online ISSN: 2052-6407(Online)

\section{The Chapter wise Summary of the Main Provisions of the UN Procurement Manual}

Chapter 1: Introduction and purpose Chapter 1 comprises Purpose and overview of UN Procurement manual, principles of value for money (optimization of whole life costs and quality),UN financial rules and regulations, authority and responsibility, degree and extent of competition, ways of solicitation, form of contract( oral or written), progress and advanced payment. This chapter also incorporates the exceptions regarding the formal methods of solicitation and the ways the Under-Secretary General for Management cooperate for the achievement of the requirements of the UN.

Chapter 2: Responsibilities and functions Chapter 2 discuss the functions of the procurement divisions of the UN. It also gives the indication relating to the functions of local procurement structure. Efficient support services to be ensured by the UN/PD. A director is in charge of UN/PD. This director is responsible for the operation and maintenance of UN/PD. Procurement Services Division (PSD) is categorized as Field Procurement Service (FSS) and Headquarters Procurement and Support Service (HPSS).

Chapter 3: Delegation of Procurement Authority This chapter focuses on the officials who are empowered to authorise, authority and responsibility of procurement, authority at HQ, Procurement authority at OAH \& Field Missions, individual procurement authority modification, exceptional delegation of authority, delegation regarding insurance and related services.'

Chapter 4: Ethical Standard As per UN procurement Manual, ethical standards in procurement include the following: Ethical standards and responsibilities in procurement, Oath taking, Staff regulations, Financial rules, Conflict of interest, Confidentiality, Financial Disclosure, Gifts, Hospitality, Post employment restriction, Corrupt practices, Other related administrative orders.

Chapter 5: The global compact Under the provision of the UN procurement Manual, it is expected that all the procurement staffs are very familiar with the fact that UN fosters the participation of both public and private sector vendor to engage in to the Global Compact- a voluntary international corporate network which support to face the potentials challenges of globalization. Global Compact's based on the ten basic principles.

Chapter 6: Overview of the procurement process This chapter depicts a vivid picture as to the overall procurement process of the UN. The potential vendors are to be registered with the UN system to participate in to the bidding process. Diversity of the vendors and the state or status of the economy of the participating vendor are taken in to due consideration. After being scrutinized through a rigorous process, the successful bidders turn in to a contractor and come under contractual obligation in the light of the existing rule and regulation of the UN. 
Chapter 7: Vendor registration \& management (VRM) For being registered with the UN for the purpose participation in to the bidding process, the vendors are to submit the application form through the United Nations Global Marketplace (UNGM). The UN keeps a centralized electronic register of vendors. This vendor list is made available on the UNGM and UN website. Using the pre-disclosed criteria, UN evaluate the vendors' applications whether they confirm with the UN requirements. Under the UN systems, there are Vendor Registration Officer (VRO) who are responsible for administration of vendor registration process, evaluation of vendor registration application, giving guidance the Vendor Review Committee (VRC).

Chapter 8: The acquisition Process This chapter takes in to account the overview of the acquisition process and methodologies undertaken under the UN procurement manual. It includes short term, long term planning, and annual planning. Short term planning focuses on the current budget period. Under this planning, the requisitioner tends to avoid last minute order in order to maintain budgetary discipline. Long term planning covers the time horizon beyond the short term planning, and focuses the fact that organizations utilize funds in a professional way to achieve value for money. For implementing annual plans, UN procurement offices shall communicate their requirement for incoming budget year. For the purpose of acquisition, the UN Offices define the needs and prepare specification. The specification is prepared in such a way so that it guarantees the widespread competition and this is how, ensures value for money. The main essence of the specification is that it does not refer to any particular product or brand name. If particular product is the only choice, in that case the words "Equivalent" must be mentioned in the specification. The specification is expected to be clear and free of any ambiguity.

Chapter 9: The solicitation This chapter includes modalities of preparing for solicitation and vendor selection, methods of selection, and terms and conditions. For solicitation and vendor selection, solicitation documents are prepared and issued. During doing this, UN procurement officer should factor a number of issues in the source selection plan

Chapter 10: Management and treatment of vendors This chapter deals with the following issues, Receipt of submissions, Facsimile submissions, Submission via electronic method, Protecting submission, Unsolicited submission, RFQs submission, Submission withdrawal, Modification of submission, Modifications followed by errors \& omissions, Errors in affixing signature, Errors originated due to clerical mistake, Submission \& extension of deadline, Public submission, Opening attendance, Availability of information.

Chapter 11: The Source selection process This chapter take in to account the following aspects: Source selection, Vendor determination, Submission rejections, Source selection plan, Evaluation committee, Technical evaluation team, Responsibility of the commercial evaluation team, Evaluation criteria, Classification of evaluation criteria, Evaluation criteria categorization, 
Vol.8, No.3, pp.14-33, May 2020 Published by ECRTD-UK

Print ISSN: 2052-6393(Print), Online ISSN: 2052-6407(Online)

Weighting and rating system, Source selection process, Source selection process procedures, Adherence to solicitation documents, Use of solicitation abstract sheet for evaluation, Scope for seeking clarification, Commercial proposal opening, Opening of commercial submission of technically non- compliant. This chapter also discuss various selection criteria which are as follows: Commercial criteria, Face value of the goods, works and services, Whole life costing or total cost of ownership or life cycle costing, Financial capability, Non- financial cost, Technical criteria, Management criteria, Management experience, Quality commitment, Qualification and experience of the personnel, Facilities, Financial management.

Chapter 12: Functions of, and Review by the Headquarters Committee on Contracts This chapter consists of the ten sections, namely, organization and functions of the HCC, organization and functions of the LCC, review by the HCC, review by the LCC, submissions to contracts committee, role of procurement offices, pre-clearance measures by the HCC, meetings and decisions of the contracts committees, special provisions for emergency situations, and ex-post facto presentations. Some highlighted issues of this chapter is discussed below:

In order to face emergency situations, the chairperson of a contracts committee, in accordance with the guidelines of the UN Procurement Manual, may accept late submissions of presentations. There are two types of cases that require presentation to contract committees, for example, "expost facto", and partially "ex-post facto".

Chapter 13: Contractual Instruments This chapter is divided in to 13 sections, namely, introduction to contractual instruments, UN's contractual instrument, internal purchase orders, blanket purchase orders, purchase order, customized contracts, standard contract documentation, standard contract elements, systems contracts, institutional or corporate contractor agreement, letters of assists, use of letters of assists, and other contractual elements.

Chapter 14: Delivery and Receiving Process This chapter consists of seven sections, namely, introduction relating to delivery and receiving of goods and services, guidelines for recording and receiving, responsibilities of UN/PD, procedures for UN/PD, inspection of goods and services in IMIS, returning material to vendor, and issues from the stores.

Chapter 15: Contract Management and Administration This chapter takes in to account of the issues like pros and cons of the contract management, evaluation of vendor performance management, remedies, dispute resolution, contract administration, sub contractor, contract closure, maintenance of files, and contract log.

Chapter 16: Property Disposal This chapter ponders over the issues like property survey boards, disposal of property through sale, treatment of bids, contractual instruments for the sale of goods, 
Print ISSN: 2052-6393(Print), Online ISSN: 2052-6407(Online)

exceptions to solicitation, deposits, notice of award billing, removal of property, disposition of assets of peacekeeping operations, and sale of real property.

Analysis and Findings An in-depth analysis of the PPR-2008, Standard Request for Proposal (PS 4 and PS 12) shows that there are several areas where there are similarities between the provisions of PPR 2008 with the provisions of the UN Procurement Manual. On the other hand, there are some areas where there are differences between the provisions of PPR 2008, particularly, PS4 and PS 12 with the provisions of the UN Procurement Manual. Major findings of the study are presented below:

General principles of Procurement UN procurement is guided by the general principles as ensuring the best value for money, fairness, integrity, and transparency, effective international competition, and keeping the interest of the UN. On the other hand, the purposes of the PPA/PPR are to ensure free and fair competition with highest value for money. Ensuring economy, efficiency and effectiveness in the arena of public procurement in Bangladesh.

Preparation of Procurement plan UN procurement manual made it compulsory to prepare a procurement plan and got it approved by the competent authority. As per rule 16 of the PPR-2008, the procuring entity shall prepare procurement plan for the development budget and revenue budget at the beginning of each financial year.

Ethical issues in procurement A comparative statement regarding the ethical issues of procurement that exist in the UN Procurement manual and PPR-2008 are depicted in the table below:

Table 1: A comparative account of the ethical issues noted in the PPR-2008 and UN Procurement Manual

\begin{tabular}{|l|l|l|}
\hline Name/ Nature of ethical issue & $\begin{array}{l}\text { Existence at UN Procurement } \\
\text { Manual }\end{array}$ & Existence at the PPR-2008 \\
\hline Oath of the office & Yes (Chapter 4.2) & No \\
\hline Conflict of interest & Yes (Chapter 4.5) & Yes (Rule 55) \\
\hline Confidentiality & Yes (Chapter 4.6) & Yes [Rule 8.1 and 8.2] \\
\hline $\begin{array}{l}\text { Financial disclosure/Wealth } \\
\text { statement }\end{array}$ & Yes (Chapter 4.7) & No \\
\hline Gifts and hospitability & No (Chapter 4.8) & No (Rule 127) \\
\hline Corrupt practices & No (Chapter 4.10) & No (Rule 127) \\
\hline
\end{tabular}

Source: Developed by the author (s). 
Global compact The UN Procurement system promotes corporate citizenship and support to uphold human rights, labour standard, and environmental sustainability. In the PPR 2008 does not contain any direct provision regarding the above issues.

Vendor Registration and Management UN procurement manual requires all the vendors to be registered with the UN registration portal (www.ungm.org). In PPR-2008, vendor's registration with the CPTU (http://www.cptu.gov.bd) is mandatory for the online tendering process. In Bangladesh, both offline (manual) and online [ (e-gp: Electronic Government procurement)] tendering methods are accepted. However, as per rule 63 of PPR-2008, under Limited Tendering Method (LTM) tenderers are to be enlisted with the different procuring entities.

Funding requirement Chapter 8.4 of the UN procurement manual states that it is to be ensured that sufficient funding is available for the particular procurement before issuing the requisition to the procurement office. In case of PPR-2008, funding assurance is not mandatory. If the procuring entity feels the necessity, then having approval from the head of the procuring entity, and updating the annual procurement plan, the procurement process may be undertaken.

Market survey UN procurement manual requires to conduct market survey in order to find the qualified and capable sources that can satisfy the needs and requirement. Prior discussion with the vendors regarding the latest specification is encouraged so that knowledge gap is minimized. Rule $16(5)(\mathrm{ka})$ and $16(5)(\mathrm{kha})$ of PPR -2208, contain the issue of conducting current market price verification so that official cost estimate is prepared.

Preparation of solicitation and vendor selection The term 'Solicitation Documents' is the UN procurement manual, while at PPR-2008, 'Standard Tender Documents' is used to denote the same meaning. In the UN system, formal methods of solicitations are established by the UN's financial regulations. Under the current procurement system, standard tender documents are prepared based on the individual needs, nature and threshold kevel of the procurement of goods, works and services. 
Some other solicitation related issues are given below:

\section{Table 2: Some Comparison}

\begin{tabular}{|c|c|c|}
\hline Name/ Nature of issue & $\begin{array}{l}\text { Existence at UN Procurement } \\
\text { Manual }\end{array}$ & Existence at the PPR-2008 \\
\hline Evaluation of requisition & $\begin{array}{cl}\text { Based on the following issues: } \\
\checkmark & \text { Best value for money } \\
\checkmark & \text { Fairness, integrity and } \\
& \text { transparency } \\
\checkmark & \text { Effective competition } \\
\checkmark & \text { The interest of the UN }\end{array}$ & $\begin{aligned} & \text { Based on the following principles: } \\
& \checkmark \text { Fairness } \\
& \checkmark \text { Transparency } \\
& \checkmark \text { Open competition } \\
& \checkmark \text { Maintaining Economy, } \\
& \checkmark \text { Maintaining Effectiveness } \\
& \text { and Efficiency }\end{aligned}$ \\
\hline $\begin{array}{l}\text { Limited number of vendors to be } \\
\text { invited }\end{array}$ & $\begin{array}{l}\text { When good cause and justification } \\
\text { support, then with the approval of } \\
\text { the competent authority, the } \\
\text { procurement officer of the UN shall } \\
\text { invite limited numbers of vendors. } \\
\text { (Chapter } 9 \text { part-1, section 9.4) }\end{array}$ & $\begin{array}{l}\text { Rule 63, supports the limited } \\
\text { tendering methods for the goods and } \\
\text { works of specialized nature, for } \\
\text { example, aircraft, locomotives, } \\
\text { telecommunications equipments, } \\
\text { silos, ports, harbours etc. Or for } \\
\text { meeting emergency needs. }\end{array}$ \\
\hline Types and methods of solicitations & $\begin{array}{l}\text { RFQ, ITB, RFP. They are based on } \\
\text { the nature of procurement. }\end{array}$ & $\begin{array}{l}\text { OTM, LTM, DPM, TSTM, STTM, } \\
\text { Cash Purchase, RFQ, Force } \\
\text { Account, QCBS, SFB, SSS, SIC, } \\
\text { LCS, SBCQ, CSOs, DC, RFP, LOI, } \\
\text { and REOI. }\end{array}$ \\
\hline Low Value Procurement & $\begin{array}{l}\text { Up to } \$ 4000 \text {, direct procurement } \\
\text { shall be allowed. (Chapter } 9.15 \text { ) }\end{array}$ & $\begin{array}{l}\text { When specific conditions allow, } \\
\text { then direct procurement shall be } \\
\text { allowed for any value. (Rule-76 } \\
\text { ) }\end{array}$ \\
\hline $\begin{array}{l}\text { Special guidance on exigency } \\
\text { situations }\end{array}$ & Yes(Chapter 19) & Yes (Rule-76) \\
\hline Language of solicitation document & English & English \\
\hline
\end{tabular}


Vol.8, No.3, pp.14-33, May 2020 Published by ECRTD-UK

Print ISSN: 2052-6393(Print), Online ISSN: 2052-6407(Online)

Table 3: A comparative statement of the solicitation and vendor selection issues mentioned in the PPR-2008 and the UN Procurement Manual,

\begin{tabular}{|c|c|c|}
\hline Name/ Nature of issue & $\begin{array}{l}\text { Existence at } \quad \text { UN } \\
\text { Procurement } \\
\text { Manual }\end{array}$ & Existence at the PPR-2008 \\
\hline Total cost of ownership & Yes (Chapter 9.27) & No \\
\hline $\begin{array}{l}\text { Period of validity of } \\
\text { bids/tender and proposals }\end{array}$ & $\begin{array}{l}\text { Usual validity period ranges } \\
\text { from } 60 \text { to } 180 \text { days. (Chapter } \\
9.30 \text { ) }\end{array}$ & $\begin{array}{l}\text { Usual validity period ranges } \\
\text { from } 60 \text { to } 120 \text { days. (Rule } \\
21.2 \text { ) }\end{array}$ \\
\hline $\begin{array}{l}\text { Inspection and Acceptance } \\
\text { clause }\end{array}$ & Yes & Yes \\
\hline Liquidated damage & $\begin{array}{l}\text { Yes (No more than } 10 \% \text { of the } \\
\text { contract price)[Chapter } 9.35]\end{array}$ & $\begin{array}{l}\text { Yes (No more than } 10 \% \text { of the } \\
\text { contract price)[Mentioned in } \\
\text { the STD] }\end{array}$ \\
\hline Clarification of request & Yes (Chapter 9.49) & Yes (Rule 98.8) \\
\hline Use of INCOTERMS & Yes & Yes \\
\hline Use of standard documents & Mandatory & Mandatory \\
\hline $\begin{array}{l}\text { Clause relating to rejection of } \\
\text { all submission without } \\
\text { showing reasons }\end{array}$ & Yes & Yes \\
\hline
\end{tabular}

Source: Developed by the author (s). Terms and conditions related issues 
Vol.8, No.3, pp.14-33, May 2020 Published by $\boldsymbol{E C R T D}-\boldsymbol{U K}$

Print ISSN: 2052-6393(Print), Online ISSN: 2052-6407(Online)

Table 4: A comparative inclusion relating to the terms and conditions issues as mentioned in the PPR-2008 and the UN Procurement Manual,

Management and treatment of vendor submissions Issues relating to management and treatment of vendor submissions are depicted below:

\begin{tabular}{|c|c|c|}
\hline Name/ Nature of issue & $\begin{array}{l}\text { Existence at UN Procurement } \\
\text { Manual }\end{array}$ & Existence at the PPR-2008 \\
\hline Electronic submission & Yes & Yes \\
\hline $\begin{array}{l}\text { Opening of submissions received } \\
\text { in response to RFQs }\end{array}$ & No public opening & No public opening \\
\hline $\begin{array}{l}\text { Provisions pertaining to } \\
\text { withdrawal, modification and } \\
\text { substitution of submissions }\end{array}$ & Yes & Yes \\
\hline Clerical errors & $\begin{array}{l}\text { Accepted and corrected by the } \\
\text { competent committee. }\end{array}$ & $\begin{array}{l}\text { Accepted and corrected by the } \\
\text { evaluation committee. }\end{array}$ \\
\hline Receipt of late submission & $\begin{array}{l}\text { Normally rejected, but if the } \\
\text { Director UN/PD (or CPO) thinks } \\
\text { that late submission occurred due } \\
\text { to the fault of the UN in that case } \\
\text { late submission can be accepted. }\end{array}$ & $\begin{array}{l}\text { Under PPR-2008, all late } \\
\text { submissions are rejected straight. }\end{array}$ \\
\hline Opening of proposal & $\begin{array}{l}\text { Public opening of technical } \\
\text { proposals is allowed. Financial } \\
\text { proposal are kept unopened } \\
\text { during this period. }\end{array}$ & $\begin{array}{l}\text { Non-public opening of technical } \\
\text { proposal and public opening of } \\
\text { financial proposals of technical } \\
\text { proposals. (Rule 105.2) }\end{array}$ \\
\hline $\begin{array}{l}\text { Disclosure of information prior } \\
\text { to opening }\end{array}$ & $\begin{array}{l}\text { Not disclosed by the submission } \\
\text { opening officer. }\end{array}$ & $\begin{array}{l}\text { Though there are not direct } \\
\text { indications at PPR-2008, the } \\
\text { TOC shall not disclose anything } \\
\text { regarding submission. }\end{array}$ \\
\hline
\end{tabular}

Source: Developed by the author. 
Vol.8, No.3, pp.14-33, May 2020 Published by ECRTD-UK

Print ISSN: 2052-6393(Print), Online ISSN: 2052-6407(Online)

Table 5: A comparative discussion relating to the Management and treatment of vendor submissions issues as mentioned in the PPR-2008 and the UN Procurement Manual

Facets of source selection process are presented below

\begin{tabular}{|c|c|c|}
\hline Name/ Nature of issue & $\begin{array}{lll}\text { Existence at } & \text { UN } \\
\text { Procurement } & & \\
\text { Manual } & & \end{array}$ & Existence at the PPR-2008 \\
\hline $\begin{array}{lr}\text { Submission } & \text { from } \\
\text { receivership, liquidation or } \\
\text { bankruptcy }\end{array}$ & Not allowed & Not allowed \\
\hline Source selection committee & $\begin{array}{l}\text { For large, costly and complex } \\
\text { acquisition projects, there is } \\
\text { provision of formation of } \\
\text { source selection committee. }\end{array}$ & No such committee is formed. \\
\hline Formation of EC & $\begin{array}{l}\text { Generally EC is divided in to } \\
\text { a Technical Evaluation Team } \\
\text { responsible for technical } \\
\text { evaluation, and Commercial } \\
\text { Evaluation Team responsible } \\
\text { for commercial evaluation. }\end{array}$ & $\begin{array}{l}\text { Only EC shall perform the } \\
\text { task of evaluation. If needed, a } \\
\text { separate technical sub- } \\
\text { committee can be formed. }\end{array}$ \\
\hline $\begin{array}{l}\text { Characteristics of Evaluation } \\
\text { criteria }\end{array}$ & $\begin{array}{l}\text { Evaluation criteria are } \\
\text { characterized by: discrete, } \\
\text { reliable, practical, fair, } \\
\text { balanced action. }\end{array}$ & $\begin{array}{llr}\text { Evaluation criteria } & \text { are } \\
\text { characterized by: } & \text { non- } \\
\text { discriminatory, open, equal } \\
\text { for all. }\end{array}$ \\
\hline
\end{tabular}

Source: Developed by the author (s).

\section{Relevant Lessons for Bangladesh}

The main objective of the UN procurement manual is to acquire goods, works and services at a cost that reflect best value for money, taking in to consideration of all the aspects of the economic, social and environmental sustainability. On the other-hand, the prime motto of the PPR-2008 are to procure goods and related services, works and related physical services and intellectual and professional services at a lower cost with desired quality that reflect value for money. Considering above discussion and findings, we may put forward the following lessons for Bangladesh: 
International Journal of Business and Management Review

Vol.8, No.3, pp.14-33, May 2020

Published by ECRTD-UK

Print ISSN: 2052-6393(Print), Online ISSN: 2052-6407(Online)

Sustainability Current version of PPR-2008 does not contain the aspects of sustainability. Hence, the issues relating to responsible procurement, green procurement should be included in the PPR2008 in line with the Sustainable Development Goals (SDSs).

Disposal Policy During procurement or acquisition of an asset, the cost of disposal that may accrue at the end of the expected life of the asset should also take in to cognizance. For ensuring true value for money, total cost of the asset may be considered at the time of acquisition of the asset.

Life cycle costing, whole life costing The concept of Life cycle costing, whole life costing, can be incorporated in the PPR-2008. Without taking in to cognizance of the pattern of asset costing, time value of money, performance of the asset over time, time value of money cannot be achieved. Methods of procurement There are 14 methods of procurement in PPR-2208. Each method has its own modality. Both the tenderers and the P.Es do not feel comfortable with so many procurement methods. Some methods can be merged together so that it can be easier to deal with. Set up a separate law wing A separate legal set up to be established under the guidance of CPTU and is to be included in the rules. As per PPR-2008, an independent review panel is working at CPTU to address the complaints raised by the tenderers and the P.Es. Another issue is that according to rule 130(1) of the PPR-2008, DG, CPTU has been empowered to give opinion relating to the confusion about the provisions of PPR. For these reasons, a separate law wing may be established to see the legal matters on behalf of the DG, CPTU.

Evaluation criteria should be modified The existing evaluation criteria should be classified based on commercial criteria, technical criteria, management criteria and sustainability criteria. These criteria should be made measurable and quantifiable using SMART criteria.

CPTU to be turned in to an Independent Body CPTU as a nodal agency need to be restructured and converted in to an independent authority so that it can have power of enforcement. At the given existing structure of CPTU, it cannot enforce anything. It can only give instructions, opinions and other support to the stakeholders.

\section{RECOMMENDATIONS AND CONCLUSIONS}

\section{Conclusions}

This paper investigated the similarities and dissimilarities between the provisions of the UN procurement manual and PPR-2008 by using method of comparison and case study. Because Bangladesh adopted PPR in 2008, since than all the amendments are taken in to cognizance. The 
International Journal of Business and Management Review

Vol.8, No.3, pp.14-33, May 2020

Published by ECRTD-UK

Print ISSN: 2052-6393(Print), Online ISSN: 2052-6407(Online)

main purpose of this paper is to address the question whether there are any differences and any analogy between the contents of the UN procurement manual and PPR-2008. The results suggest that there are some areas where similarities exist and there are some areas where significant difference exist. This may be due to the fact that PPR has been developed based on the socioeconomic structure of Bangladesh and UN procurement manual has been implemented considering the global aspect of international business environment. Another important finding is that there were some major qualitative changes in the procurement management arena in Bangladesh after implementation of PPR. In conclusion, the weak areas of PPR-2008, identified, in compared to UN procurement manual, can be eliminated in the subsequent amendments. And this s very imperative in streamlining the national procurement arena and ensure value. However, effective and efficient implementation procedure of PPR may contribute more to the smart public procurement management and economic growth in Bangladesh.

\section{Recommendations}

The identified lessons Bangladesh could implement in the following two levels: one is on the policy level, and the other is on the functional or operational level.

Policy level Most of the lessons that Bangladesh could learn may be implemented through policy level. The incorporation of the issues like total cost of ownership, responsible procurement, sustainability in procurement, disposal policy of the asset, life cycle costing, whole life costing, restructuring CPTU, translating the STDs in to Bengali language require intervention from the policy level. To bring this lessons in to reality, the existing PPA-2006, PPR-2008 need to be modified and this require the final approval of the cabinet and parliament of Bangladesh.

Functional/Operational level The policy which are adopted at the policy level are carried out by the operational or functional level. All the policies are gone through this level and the efficiency of this level is of paramount importance. The employees of this level need to be trained and oriented with the newly adopted system and procedure. It is also required to build commitment, cooperation, and mutual exchange among the employees of the functional level.

Scope for further study This study has been conducted within the purview of the PPA, PPR and UN Procurement Manual. Efforts have given to elicit the learning points and knowledge gap by means of qualitative analysis and ultimately identified certain points which need to be addressed by further study. The future researchers will have room for conducting research in those areas and may give further observations and findings. 
Vol.8, No.3, pp.14-33, May 2020 Published by ECRTD-UK

Print ISSN: 2052-6393(Print), Online ISSN: 2052-6407(Online)

\section{References}

1. Ambe, Badenhorst \& Weiss, (2012) "procurement challenges in the south african public sector”, Journal of Transport and Supply Chain Management, , Vol. 6 Issue: 1. Retrieved April 27, 2018 from https://jtscm.co.za/index.php/jtscm/article/view/63/59

2. Jones D.S, (2007) "Public procurement in southeast asia: Challenge and reform", Journal of Public Procurement, Vol. 7 Issue: 1, pp.333, https://doi.org/10.1108/JOPP-07-01-2007-B001

3. http://www.cptu.gov.bd

4. http://www.cptu.gov.bd/standard-documents.html

5. http://www.cptu.gov.bd/standard-documents/standard-tender-document.html

6. http://www.cptu.gov.bd/standard-documents/standard-request-for-proposal.html

7. McCrudden, (2004) "Using public procurement to achieve social outcomes" , A United Nations Sustainable Development Journal, Retrieved April 242018 from https://onlinelibrary.wiley.com/doi/abs/10.1111/j.1477-8947.2004.00099.x

8. United Nations Procurement Manual, Revision 7, 01 July 2013, downloaded on $20^{\text {th }}$ January 2018 from https://www.un.org/Depts/ptd/bulletins/procurement-manual-revision70-published-1-july-2013

9. The Public Procurement Act, 2006, Government of the People's Republic of Bangladesh Official Gazette, Dated: $27^{\text {th }}$ January 2008.

10. The Public Procurement Rules, 2008, Government of the People's Republic of Bangladesh Official Gazette, Dated: $27^{\text {th }}$ January 2008. (Amended as on $24^{\text {th }}$ November 2016)

11. World Bank.2002.Bangladesh-Country procurement assessment report, Washington DC: $\begin{array}{lllll}\text { downloaded } & \text { on } & 20^{\text {th }} & \text { April } & 2020\end{array}$ from http://documents.worldbank.org/curated/en/812041468743656486/pdf/multiOpage.pdf

12. www.ungm.org

13. https://tradingeconomics.com/bangladesh/gdp-growth 